\title{
A DOMINAÇÃO FILIPINA - ALGUNS ASPECTOS POSITIVOS
}

\author{
Francisco Casado Gomes \\ Pôrto Alegre
}

Aqui estamos para lembrar a data histórica que é $1 .^{\circ}$ de dezembro de 1640, histórica e grande justamente por assinalar o fim de um período de tristeza, luto e justa revolta.

Repisar os fatos dolorosos que ocorreram desde 1580 a 1640 - penso ser inútil, porque todos os conhecemos e os deploramos. Mas, haverá maneira de estudar êste longo periodo, excessivamente longo por causa de tudo que nêle aconteceu, sem recordar os aspectos trágicos da derrota, da expectativa, da prepotência e da palavra não cumprida?

Penso que sim.

E possivel encontrar fatos positivos, vantajosos, louváveis e até providenciais para Portugal e Brasil, que ocorreram naqueles anos filipinos.

Primeiramente, que seja lembrada a verdade histórica: Filipe II da Espanha tinha também um certo direito ao trono português, já que era neto de $D$. Manuel, e subiu ao trono por aclamação das côrtes e não por imposição das armas.

Em segundo lugar: não houve um só português que quisesse enriquecer, manchando as mãos no sangue de D. Antônio, prior do Crato.

E já temos dois pontos positivos, e bem interessantes para sociólogos, políticos e historiadores, principalmente se lembrarmos que Filipe foi eleito e aclamado pela maioria de um único voto...

A democracia funcionou como numerolatria, e não devemos 
esquecer que $D$. Antônio e $D$. Catarina tentaram negociar com Filipe os respectivos direitos ao trono português, e que esta última contentou-se com honrarias, em prejuizo e detrimento da honra nacional.

Aqui está outra lição histórica, válida para nossos dias: nem sempre os candidatos que se apresentam são dignos do apoio e aplauso da Nação, e nem sempre um grande número de interessados sabe resolver com melhor acêrto que uma só cabeça. $D$. Henrique, o cardeal, fêz bem em não acedendo à sugestão de êle pessoalmente tentar engendrar um quarto possível contendor, porque se o fizesse - é bem provável que Filipe se impusesse pelas armas.

Mas, do desacertado acêrto eleitoral decorreram outros benefícios.

Portugal, por muito sofrer, uniu-se. Por aprender a chorar. penitenciou-se e redimiu-se.

Voltado que sempre estivera para os mistérios. delicias e lucros do além-mar, passa a valorizar e amar a Metrópole.

Sob a camada cultural do barroco, cheia de requintes e de angústias, sob aquela falta de naturalidade e ausência de singeleza, apesar do artificialismo da palavra ou da vazia comparação de agudos conceitos, equívocos e paradoxos, mesmo sob aquela aparência de charadas literárias, registradas nas antologias do tempo, só legíveis por iniciados, que sabiam ou pretendiam saber todo o valor das hipérboles, metáforas e perífrases, algo de positivo havia, e que só há pouco foi notado, e magistralmente demonstrado, pelo Sr. Prof. Dr. Hernani Cidade.

No barroco há, além dessa camada exterior, uma grande inquietude, uma real valorização da vontade, uma fuga providen. cial à realidade, já que precisavam encontrar um ideal, já que sentiam a necessidade de fazer uma auto-afirmação pessoal e grupal, uma ânsia de desvendar o incognoscível, o mistério, o além-hoje, algo de novo, já não uma busca idealista e pragmática de novos mundos geográficos, mas intelectuais; o desejo de viver melhor, uma espécie de "sursum corda" da burguesia, que 
desejava aristocratizar-se, por já não haver uma aristocracia que the merecesse respeito.

Os fatôres sensoriais, pictóricos e musicais são fàcilmente perceptíveis, e qualquer pessoa menos avisada pode deixar-se levar por fictícias relaçōes, por vínculos artificiais entre idéias e realidades, o que é tão frequiente ainda hoje, principalmente quando a realidade é triste e o sonho é lindo.

Ora, os portuguêse's da época filipina aproveitaram-se dessas disposições psicológicas e fizeram uma literatura culteranista, até há pouco desprezada, mas... leiamo-la com atenção, e nela encontraremos não uma fuga ao passado, mas uma heróica retirada, uma espécie de intervalo ou interregno para a reorganização tendo em vista um futuro próximo.

Já que eram obrigados a suportar a triste realidade da vida dura de então, refugiam-se na arte, e o desejo de uma nova ordem político-social leva-os ao exagêro da ordenação artística, à super-estilização, e a arte passa a artifício por estar vinculada àquele presente.

Mas, o povo que era dominado por um rei que não os amava, e-que dêles se servia, volta-se o povo para um Rei a quem já haviam servido e queriam que êle os servisse, e assim unem Deus à Pátria.

Portugal passa a lembrar a época gloriosa em que venciam o infiel na Península ibérica e no Continente africano. Tem convicção de que ainda não deixara de ser o Alferes da Fé, e que, portanto, Deus não lhes faltaria.

A Nação escolhida para dilatar a fé não poderia estiolar sob o guante de um rei-ditador, e por isto esperam um novo Messias, um novo chefe político, um "Encubierto', um outro rei Artur, alguém que "entre sombras e dizeres" deveria erguer-se para levá-los a viver um novo fado, e chegavam a ouvir o grito de alerta, que Fernando Pessoa percebeu ainda:

"Sperai! Caí no areal e na hora adversa" mas

"Que importa o areal e a morte e a desventura

SE' com Deus me guardei?" 
E os portuguêses compreendem, então, a dura verdade que o grande poeta viu:

"Triste de quem é feliz.

Vive porque a vida dura. (...)

Ser descontente é ser homem.

Que as fôrças cegas se domem

Pela visão que a alma tem."

E a tristeza e a infelicidade os levou à visão e até à aceitação plena do sebastianismo, em sua dupla modalidade, à D. João de Castro e à P. Antônio Vieira, sebastianismo que fecundou a arte e suavizou a vida, e que ainda hoje está presente na literatura portuguêsa contemporânea.

Graças à visão da alma lusa, a profecia camoniana realizou-se. D. Sebastião foi, em 1640, a "bem nascida segurança / Da lusitana antigua liberdade". Apenas, não foi êle mesmo o restaurador definitivo da liberdade nacional, mas foi um descendente de João I, mestre de Avis e de "Nuno fero', do "forte dom Nuno Álvares" que, "por nenhum respeito / O próprio reino" queria ver sujeito, e que prometera "Vencerei não só êstes adversários / Mas quantos a meu rei forem contrários".

E os adversários eram os filipistas, e o próprio rei; por isto os intelectuais recorrem a velhas profecias e a afirmativas de astrólogos, como o fizeram Pereira de Castro, Manuel Bocarro e P. Vieira. E, com o decorrer dos anos passam do sebastianismo espectativa para o sebastianismo oportunista.

Até a ciência tenta colaborar com o sagrado desejo de autonomia e com o sonho do $5 .^{\circ}$ Império, que se fortaleceu com o documento forjado por Bernardo de Brito.

A historiografia assume tons épicos e une a memória do passado de glórias militares às convicções religiosas do presente e ao anseio de independência política, haja à vista os trabalhos de Frei Luis de Sousa, do P. Antônio de Vasconcelos e de Manuel de Faria e Sousa.

Muitos procuram provar a superioridade militar lusa e até a 
superioridade religiosa, para mostrar que os Filipes só haviam começado a ser grandes, quando já haviam passado a ser reis de Portugal.

Aliás, já vinha do século anterior a ufania lusitana e o nacionalismo, que tudo elogiavam desde que fôsse português. $E \circ$ anti-castelhanismo, já existente em 1500, avoluma-se no seiscentos, e é ềie que dá a independência a Portugal.

O espírito de ufania-autonomia aparece nitidamente na poesia épica, que não só recorda o passado e louva a expansão marítima, como até chega a lembrar as vitórias bélicas sôbre a Espanha, como o fizeram Gabriel Pereira de Castro e Francisco Rodrigues Lôbo. Este encomiou a Casa de Bragança e elogiou D. Nuno, o Condestabre, cujos feitos deveriam servir de exemplo e alento para novas glórias, como as desejadas por Antônio de Sousa de Macedo.

Até os teólogos portuguêses aderiram à mentalidade autonomista, e fizeram a corajosa propaganda da verdadeira democracia, defendendo o direito da eleição do Chefe pelo povo, como se vê dos estudos de Manuel de Sá, Francisco Suarez e Jerônimo Osório, e muitos mestres juristas subscreveram essas opiniões, tais como Pedro Barbosa Homem e Salgado de Araújo. Muitos foram os escritores que dedicaram suas obras a elementos proeminentes da Casa de Bragança, como por exemplo: Jerônimo Côrte Real, Antônio de Sousa, Francisco Rodrigues Lôbo, Manuel Bocarro e Agostinho de Vasconcelos.

Assim, os intelectuais e o povo em geral, desejosos da autonomia, localizavam seu anseio messiânico-sebastianista na $\mathrm{Ca}$ sa de Bragança, e esta exigência passa às provincias ultramarinas vai à Africa e à India, e aqui no Brasil encontra seu propugnador na pessoa de Antônio Vieira.

Aqui e lá na Metrópole, todos querem um rei lusitano, e o povo em tudo vê vaticínios, profecias e milagres, que ratificam o seu desejo.

O Império expandira e defendera a Fé, agora deveria ser a Fé a defender o Império, o passado em função do presente. 
Até o mito de Ulisses, que "sem existir nos bastou"; a lembrança de Viriato, cujo "ser é como "aque!a fria / luz que precede a madrugada"; o elogio de Nun' Álvares, "Sperança consumada, /S. Portugal em ser; o encômio a Afonso de Albuquerque que, "De pé, sôbre os países conquistados / Desce os olhos cansados / de ver o mundo e a injustiça e a sorte", todos fazem com que tôda a gente ouça uma voz que "vem no som das ondas". mas "que não é a voz do mar" porque é a voz do anseio nacional, grito de esperança apenas balbuciado com a razão, mas bradado bem alto pelo coração de todos os portuguêses de aquém e além mar, e que se expressa pelo lirismo também e pelo sentimento respeitoso da dignidade de pessoa e de povo.

Aqui no Brasil, graças ao período da dominação filipina, os nossos homens abrem mais largos horizontes, indo muito além dos fixados pelo Tratado de Tordesilhas. As entradas e bandeiras, movimentos que têm algo do espírito épico henriquino, ampliam o nosso território, levam a língua e os costumes lusos até o "hinterland", e fazem do Brasil litorâneo um país continente, graças às marchas forçadas para o oeste, para o norte e para o sul.

E foi êste Brasil grande e forte que mais tarde iria amparar e financiar Portugal.

Este mesmo Brasil que já soubera opor-se às invasões francesas e holandesas, que já tivera a nítida percepção de que poderia autodefender-se graças a seus próprios recursos, e que já unira as três raças tristes que o habitam, êste mesmo Brasil quis continuar a ser província ultramarina portuguêsa.

$O$ exórdio do merecidamente célebre sermão que Vieira aqui pronunciou, na Igreja de N. S. da Ajuda, em princípios dé maio de 1640, o sermão "Pelo bom sucesso das armas de Portugal contra as de Holanda", e que é um apêlo dramático ao Providencialismo, bem poderia ter sido dirigido - não a Cristo Sacramentado - mas ao Duque de Bragança: "Levanta-te. Por que dormes, Senhor? (...) Esqueces-te da nossa miséria e da no:sa tribulação? Levanta-te, Senhor, ajuda-nos e redime-nos em atenção ao teu nome."

É também por essa época que, na Bahia e em Pernambuco 
a nossa língua e a cultura de Portugal são estudadas com afinco e amor. Aqui já havia, então, graças às providências da Metrópole, apesar de viver em regime deficitário, um centro cultural de tal envergadura que possibilitara a Antônio Vieira adquirir a admirável cultura com que impressionou Lisboa, em 1641.

Aqui estiveram, na época filipina, Fernão Cardim, o evorense que foi o precursor da nossa historiografia, "graças à sua "Narrativa Epistolar" e aos dois tratados sôbre o Brasil; Cabriel Soares de Sousa que escreveu o "Tratado descritivo do Brasil", e Bento Teixeira que redigiu a sua "Prosopopéia", e Antônio Vieira, que tantas cartas e sermões aqui escreveu.

É nessa época que o Brasil cresce e começa a enriquecer, em que os homens se extasiam diante da grandeza e imponência da natureza brasílica ou se preccupam com a miséria física dos brasis e com a miséria moral de muitos "brasileiros", comc ocorreu a D. Francisco Manuel de Melo.

Foi durante a dominação filipina que aqui apareceram: Eusébio de Matos, "êmulo de Vieira e rival de Antônio Sá"; Manuel de Moraes, o autor das "Memórias históricas sôbre Portugal e Brasil"; Frei Vicente do Salvador, que escreveu a "História da Custódia do Brasil", e - por fim - o poeta lírico e satírico, a nossa versaao de Bocage - Gregório de Matos, o Boca do Inferno.

E êsses autores são os que vieram iniciar a nossa literatura, dar princípio e fundamento à nossa incipiente cultura luso-brasileira.

Eis, em mui rápida síntese, o balanço do que ocorreu nos 60 anos em que Portugal viveu sob os Filipes, balanço que apresenta um bom "haver", muito de positivo para as duas Nações, um bom crédito a favor de ambas, no sentido de progresso material e intelectual.

Portugal muito sofreu em seus filhos e muito perdeu de seus antigos territórios, mas ganhou em união e em patriotismo, em aumento do território brasileiro e no respeitoso amor comprovado dos brasileiros, que não titubearam em mandar a Lisboa a célebre comissāo escolhida pelo Marquês de Montalvão, que 
ia saudar D. João IV e oferecer-lhe os nossos préstimos e obediência, justamente nos dias em que Portugal mais necessitava de auxílio e apoio.

E nós mandamos aquela comissão porque bem sabíamos o que devíamos à nobreza, ao clero e ao povo de Portugal, que tanto nos tinham auxiliado na luta desigual contra os batavos.

E Portugal nos valorizava tanto que $D$. João IV determinou que o título dos príncipes primogênitos fôsse "Príncipe do Brasil e Duque de Bragança".

Aliás, desde essa época, a família imperial portuguêsa olhava o Brasil como o local seguro em caso de perigo eminente para a coroa e para a soberania nacional, dando assim a sugestäo que mais tarde foi aproveitada por $D$. João $V I$ e pelos milhares de outros portuguêses que aqui vieram $e$ vêm ter porque sabem que aqui sempre encontrarão um clima propício para iniciar uma vida digna e laboriosa, porque para os portuguêses viver no Brasil não é afastar-se da Pátria, porque aqui trabalhar é continuar a engrandecer Portugal. 